\title{
Review
}

\section{One health approach of campylobacteriosis in Egypt: An emerging zoonotic disease}

\author{
Wafaa A Abd El-Ghany \\ Poultry Diseases Department, Faculty of Veterinary Medicine, Cairo University, Egypt
}

\begin{abstract}
World Health Organization (WHO) defined zoonotic diseases as diseases transmitted from animals to humans and vice versa with or without vector, where more than $75 \%$ of the human's diseases have been transmitted from animals or their products. Nevertheless, campylobacteriosis is still one of the most important food borne zoonotic diseases that is likely to challenge global public health all over the world. In Egypt, campylobacteriosis causes severe losses in comparison with other food borne pathogens like Salmonella or Escherichia coli. The potential sources of Campylobacter transmission are poultry backyards and meat, cattle meat, raw milk and water. The main clinical manifestations of human's campylobacteriosis are gastroenteritis and later on nervous signs. Prevention and control strategic plans of campylobacteriosis are very crucial.
\end{abstract}

Key words: Campylobacter spp.; Egypt; epidemiology; diagnosis; control.

J Infect Dev Ctries 2019; 13(11):956-960. doi:10.3855/jidc.11860

(Received 21 July 2019 - Accepted 20 September 2019)

Copyright (C) 2019 Abd El-Ghany. This is an open-access article distributed under the Creative Commons Attribution License, which permits unrestricted use, distribution, and reproduction in any medium, provided the original work is properly cited.

\section{Introduction}

Campylobacteriosis has long been recognized as serious food borne zoonotic disease of worldwide public health threat. Campylobacteriosis caused by Campylobacter jejuni (C. jejuni) or Campylobacter coli (C. coli) is responsible for gastroenteritis in human [1]. Recently, infection with Campylobacter organisms is likely to challenge global public health either in developing or developed industrial countries. Different international strategies were planned to reduce the risk of Campylobacter transmission [2]. Despite public health burden associated with campylobacteriosis, the disease situation remains difficult to be exactly estimated in developing countries as a result of lacking of a national surveillance system [3]. Therefore, implementation of periodical national evaluation of the foodborne campylobacteriosis is very critical issue.

So, this review will discuss campylobacteriosis epidemiological situation in Egypt, reservoirs and transmission methods, the organism pathogenesis, clinical disease manifestations, isolation and identification of Campylobacters and then emphasis on the different control and prevention interventions. Finally some suggestions will be offered from the standpoint of One Health approach.

\section{Epidemiology}

Early survey on Campylobacter infection was conducted in 1987 on acute diarrheic 126 out-patients and 25 in-patient's in southern Egypt (Aswan) where $C$. jejuni/ coli (7\%) were identified [4]. In a hospital based study in Cairo in 1991, Campylobacters were isolated from $37 / 143(25.9 \%)$ of diarrheic children compared to 20/132 (15.2\%) of non-diarrheic ones [5]. In 1995, Campylobacter spp. were isolated from 880 (16.8\%) children with diarrhea and from 1079 (6.4\%) healthy children, moreover, the isolation of Campylobacter was more frequent than Salmonella, Shigella and other bacterial enteric pathogens [6]. From 1986-1993, in Abbassia Fever Hospital, Cairo, Egypt, 6,278 patients with acute enteric infections were examined where 92 strains $(63 \%)$ of $C$. jejuni and $54(37 \%)$ of $C$. coli were isolated [7].

In 2005, military personnel with diarrhea were participated in a military exercise in the northwestern Egyptian desert and the pathogens causing diarrhea were identified in $53.6 \%$ of 129 enrolled cases. C. jejuni with other enteropathogenic bacteria, virus and protozoa were identified [8]. Similar study was conducted in 2011, on 72 personnel with travelers' diarrhea in Multinational Force and Observers camp in the Southern Sinai, Egypt and the bacteriological 
examination of their stool revealed isolation of $C$. jejuni from $7(10 \%)$ [9].

Later on, Campylobacter spp. were identified from patients with gastroenteritis in Cairo, Egypt using conventional and polymerase chain reaction (PCR) methods in $6.6 \%$ of human stool samples [10,11]. Recently, the epidemiology of Campylobacter among an Egyptian pediatric population was described and the results pointed out to the variability in Campylobacter spp. and C. jejuni capsular polysaccharide (CPS) diversity in this population; furthermore, the high prevalence of type-6 secretion system (T6SS) among $C$. jejuni isolates as there was no significant associations between clinical illness and Campylobacter spp., $C$. jejuni CPS types, or suspected virulence factors [12].

\section{Reservoirs and transmission methods}

Poultry is recognized as a primary source for Campylobacter spp. transmission to humans as strain of C. jejuni can survive in chicken droppings for up to 6 days after excretion [13]. Comprehensive studies conducted in different Egyptian governorates proved that chickens reared in farms or houses is the main source of Campylobacter infections for contact persons [14-17]. Phylogenetic tree analysis emphasized genetic relatedness among Campylobacter isolates from chickens and those from humans [18].

Processed chickens plays an important role for human foodborne campylobacteriosis in Egypt. Different types of Campylobacter spp. (C. jejuni and $C$. coli) were isolated from retail fresh or frozen chicken carcasses skin and meat $[15,19,20$,$] as well as from$ barbequed and products of chickens [21,22]. Campylobacter strains isolated from chicken carcasses showed identical molecular characterization with those in handler's employees and consumers which signifying the high possibilities of zoonotic hazards $[15,20,21]$.

Cattle and beef meat products considered as reservoir for Campylobacter spp., highlighting the importance of non-poultry farms as possible sources of human infection [23]. The population genetics approach revealed that the vast majority $(97 \%)$ of Campylobacter diseases could be attributed to farmed animals and poultry as principal sources of human disease, while wild animals and environmental sources are responsible for just (3\%) of the disease [24].

Moreover, higher percentages of Campylobacter spp. isolation from raw milk and milk products (Karish cheese, soft cheese and yoghurt) of Egyptian cattle and sheep were recorded [25-29].
Water is considered as another vital source for Campylobacter public health hazard in Egypt [28]. C. jejuni contamination of drinking water municipal plants in three locations at Giza governorate, Egypt were proved and the organisms were isolated from diarrheic patients at the surveyed locations assuredly due to drinking water from these plants [30]. However $C$. jejuni isolates were also detected in ground water samples and stool specimens from the inhabitants of the villages in Giza, Egypt [31].

\section{Pathogenesis}

Intestinal colonization and adhesion are the first and crucial stages of Campylobacter pathogenesis. Colonization is secondary to chemotaxis process by the intestinal mucus (mucins and glycoproteins) [32]. Bacterial adhesion to the host's intestinal epithelial surface is mediated by many proteins adhesins like CapA that located on the bacterium surface [33]. The resulting cell death is related to the production of several cytotoxins like Cytolethal Distending Toxin (CDT) [34]. This toxin has desoxy-ribonuclease activity and determines the cell cycle block and fragmentation of the nucleus causing cell damage.

\section{Clinical manifestations}

Campylobacter in poultry induces only diarrhea or sub-clinical infection. However in human, Campylobacter incubation period ranges from 2-7 days. The average organism shedding is $1-3$ weeks after incubation period. Symptoms of campylobacteriosis include gastroenteritis, diarrhoea, vomiting, stomach pain and fever [35]. The illness is usually self-limiting and symptoms could subside within one week; nevertheless complications like dehydration, hepatitis and neurological disorders may be noticed [3]. Campylobacter infections sequelae are Guillain-Barré Syndrome (GBS), reactive arthritis, irritable bowel syndrome and Miller Fisher Syndrome. Campylobacter isolation rates and diarrhea histories in Egyptian patients suggested that Campylobacter associated diseases are common, as well as the widespread exposure to Campylobacter infections is associated with production of antiganglioside antibodies that prompted paralysis and GBS [36]. Deaths were recorded especially in young, elderly as well as immunosuppressed persons.

\section{Isolation and identification}

Isolation and identification of Campylobacter spp. are usually done as Quinn et al. [37]. Temperature tolerance test is important to demonstrate the ability of 
isolates to grow under microaerophilic conditions $\left(25^{\circ} \mathrm{C}, 37^{\circ} \mathrm{C}\right.$ and $\left.42^{\circ} \mathrm{C}\right)$ after $72 \mathrm{hrs}$ incubation. For Campylobacter isolation, samples are inoculated in thioglycolate broth and incubated under microaerophilic conditions $\left(5 \% \mathrm{O}_{2}, 10 \% \mathrm{CO}_{2}\right.$ and $85 \%$ $\mathrm{N}_{2}$ ) at $37-42^{\circ} \mathrm{C}$ for $48-72 \mathrm{hrs}$. After enrichment, positive broth should be plated onto selective media containing blood and selective antibiotics (compete intestinal flora) like Butzler, Blaser and Skirrow media. Microscopic examination under phase contrast microscope is used for detection of characteristic Campylobacter darting motility. Films stained with Gram's to demonstrate the characteristic features of Campylobacter organisms. Biochemical and other tests that are used for identification of Campylobacter isolates include: catalase and oxidase production, nitrate reduction, $\mathrm{H}_{2} \mathrm{~S}$ production, citrate utilization, urea hydrolysis, glycine tolerance, $\mathrm{NaCl}$ tolerance, hippurate hydrolysis tests and sensitivity to nalidixic acid and cephalothin. The 16S rRNA gene, the Internal Transcribed Spacer (ITS) region and 23S rRNA genes have been used for differentiate between Campylobacter spp. and strains [38].

\section{Control and prevention interventions}

Earlier, ciprofloxacin (member of fluoroquinolones) was used successfully for the treatment of Egyptian Campylobacter travellers' diarrhea cases without resistance [39]. The emergence of resistance to quinolones in Campylobacter may be a threatening trend that has not been previously reported in Egypt [7]. The antimicrobial susceptibility among $C$. jejuni and $C$. coli recovered from rural Egyptian children from 1995-2000 revealed decreasing in ciprofloxacin susceptibility in $C$. jejuni and $C$. coli, but there was no resistance to macrolide (erythromycin or azithromycin) [40]. Lately, resistance of C. jejuni and C. coli strains isolated from Egyptian diarrheic children to fluoroquinolones was confirmed [41]. Human Campylobacter strains showed resistance $87.5 \%$ to ampicillin, $75 \%$ to streptomycin and tetracycline, $62.5 \%$ to erythromycin and $50 \%$ to chloramphenicol [14]. However, gentamicin, amikacin and chloramphenicol were the most effective antibiotics for the in vitro treatment of $C$. jejuni and $C$. coli isolates from Egyptian children suffering from gastroenteritis [11].

The risk of Campylobacter diarrhea decreases in presence of barriers to keep birds and animals out of the eating area, absence of garbage and feces on the floor of bathing facilities, stressing on mass-media public health awareness programs for changing hygiene- promoting behaviors and practices, strengthening on recent diagnostic facilities, setting up national surveillance programs as well as providing incentives from funding organizations for collaborations in Campylobacter research as other emerging disease in developing countries $[42,43]$. Public health awareness regarding the correct use of municipal and ground water for drinking or cooking only after treatment by filtration and/or boiling is important [31].

Efficient control measures at the farm contributes to reducing the risk of human infection [23]. There is a trial for preparation of Campylobacter bactericins in Egyptian chickens as it proved efficacy in prevention of Campylobacter colonization in layer flocks [44]. In human, currently there is still no approved vaccines against diarrhea associated with Campylobacter due to incomplete understanding of the pathogenic mechanisms of the disease. Probiotics are living bacteria have been shown promising results for prevention and control of $C$. jejuni colonization among Egyptian chicken farms $[45,46]$.

\section{Conclusion}

Despite campylobacteriosis is a disease of zoonotic importance in Egypt, there is a gap of knowledge about the diseases epidemiology in different localities which hinders accurate assessment of the human health burden. There is an urgent need for collaborative surveillance and intervention national plans for the control of such infection.

From the standpoint of One Health approach, a complete health surveillance program of Campylobacter infections must be done nationally to provide data about the disease occurrence and common routes of transmission. Notifications of the disease in all suffering regions should be happen rapidly, as well, it is very important to collect, analyze, and interpret data to create relationship between Campylobacter isolates of human and those of animal's origin. Increasing of the public health awareness, education and training of the target populations (Veterinarians, farm, abattoir and restaurant workers, household, nurses, doctors in hospitals, etc...) is very crucial. Biosecurity measures, vaccination or using natural competitive exclusion compounds (probiotics and acids) are very critical to reduce the risk of infection in the farm and consequently reduce the level of transmission to human.

\section{References}

1. Figura N, Guglielmetti P (1988) Clinical characteristics of Campylobacter jejuni and Campylobacter coli enteritis. Lancet 1: 942-943. 
2. Wagenaar JA, French NP, Havelaar AH (2013) Preventing Campylobacter at the source: why is it so difficult? Clin Infect Dis 57: 1600-1666.

3. Coker AO, Isokpehi RD, Thomas BN, Amisu KO, Obi CL (2002) Human campylobacteriosis in developing countries. Emerg Infect Dis 3: 237-243.

4. Mikhail IA, Hyams KC, Podgore JK, Haberberger RL, Boghdadi AM, Mansour NS, Woody JN (1989) Microbiologic and clinical study of acute diarrhea in children in Aswan, Egypt. Scand J Infect Dis 21: 59-65.

5. Pazzaglia G, Bourgeois AL, EL Diwany K, Nour N, Badran N, Hablas R (1991) Campylobacter diarrhoea and an association of recent disease with asymptomatic shedding in Egyptian children. Epidemiol Infect 106: 77-82.

6. Pazzaglia G, Bourgeois AL, Mourad AS Gaafar T, Diab AS, Hebert A, Churilla A, Murphy JR (1995) Campylobacter diarrhea in Alexandria, Egypt. J Egypt Public Health Assoc 70: 229-241.

7. Wasfy MO, Oyofo BA, David JC, Ismail TF, El-Gendy AM, Mohran ZS, Sultan Y, Peruski LF Jr (2000) Isolation and antibiotic susceptibility of Salmonella, Shigella, and Campylobacter from acute enteric infections in Egypt. J Health Popul Nutr 18: 33-38.

8. Sanders JW, Putnam SD, Gould P, Kolisnyk J, Merced N, Barthel V, Rozmajzl PJ, Shaheen H, Fouad S, Frenck RW (2005) Diarrheal illness among deployed U.S. military personnel during Operation Bright Star 2001—Egypt. Diag Microbiol Infect Dis 52: 85-90.

9. Riddle MS, Rockabrand DM, Schlett C, Monteville MR, Frenck RW, Romine M, Ahmed SF, Sanders JW (2011) A prospective study of acute diarrhea in a Cohort of United States military personnel on deployment to the multinational force and observers, Sinai, Egypt. Am J Trop Med Hyg 84: 59-64.

10. Zaghloul MZ, Farouk N, Galal ZA (2012) Detection of Cambylobacter spp. in stool samples by new methods in comparison to culture. Life Sci J 9: 2566-2571.

11. Abd El-Baky RM, Sakhy M, Gad GFM (2014) Antibiotic susceptibility pattern and genotyping of Campylobacter species isolated from children suffering from gastroenteritis. Indian J Med Microbiol 32: 240-246.

12. Sainato R, ElGendy A, Poly F, Kuroiwa J, Guerry P, Riddle MS, Porter CK (2018) Epidemiology of Campylobacter infections among children in Egypt. Am J Trop Med Hyg 98: 581-585.

13. Ahmed HA, El-Hofy FI, Ammar AM, Abd El Tawab AA, Hefny AA (2015) ERIC-PCR genotyping of some Campylobacter jejuni isolates of chicken and human origin in Egypt. Vector Borne Zoonotic Dis 15 :713-717.

14. Hassanain NA (2011) Antimicrobial resistant Campylobacter jejuni isolated from humans and animals in Egypt. Global Vet 6: 195-200.

15. Awadallah M, Ahmed H, El-Gedawy A, Saad AM(2014) Molecular identification of $C$. jejuni and C. coli in chicken and humans, at Zagazig, Egypt, with reference to the survival of $C$. jejuni in chicken meat at refrigeration and freezing temperatures. Int Food Res J 21: 1801-1812.

16. El-Tras WF, Holt HR, Tayel AA, El-Kady NN (2015) Campylobacter infections in children exposed to infected backyard poultry in Egypt. Epidemiol Infect 143: 308-315.

17. Mostafa FA, Sylvia OA, Awad AI, Hanan AM (2018) Prevalence of zoonotic species of Campylobacter in broiler chicken and humans in Assiut governorate, Egypt. Appro Poult Dairy Vet Sci 3: 1-9.
18. Ghoneim, NH, Sabry MA, Saeed ZA (2017) Zoonotic importance of Campylobacter jejuni isolated from chicken farms in Egypt. Res J Pharmaceut Biologic Chemic Sci 8: $1517-1525$.

19. Saad AEM (2014) Zoonotic importance of Campylobacteriosis at Sharkia Province. Master Thesis in Zoonosis, Zagazig University, Faculty of Veterinary Medicine, $140 \mathrm{p}$.

20. Abd El-Tawab AA, Ammar AM, Ahmed HA, El Hofy FI, Hefny AA (2015) Bacteriological and molecular identification of Campylobacter species in chickens and humans, at Zagazig city, Egypt. Benha Vet Med J 28: 17-26.

21. El Fadaly HA, Barakat AMA, Ahmed SO, Atwa AK, Omara ST, Ezzat E, Zaki MS (2016) Zoonotic concern of Campylobacter jejuni in raw and ready-to-eat barbeque chickens along with Egyptian handlers and consumers via molecular and immunofluorescent characterization. Der Pharma Chemica 8: 392-397.

22. Abd El-Aziz DM, Abd-Allah SMS (2017) Incidence of Campylobacter species in wholesale chicken carcasses and chicken meat products in Assiut city, Egypt. Int Food Res J 24: 2660-2665.

23. Khalifa NO, Afify JSA, Rabie NS (2013) Zoonotic and molecular characterizations of Campylobacter jejuni and Campylobacter coli isolated from beef cattle and children. Global Vet 11: 585-591.

24. Mohran Z, Guerry P, Lior H, Murphy JR, el-Gendy AM, Mikhail MM, Oyofo BA (1996) Restriction fragment length polymorphism of flagellin genes of Campylobacter jejuni and/or C. coli isolates from Egypt. J Clin Microbiol 34: 12161219.

25. Abdel-Hady HM (1996) DNA prob and test for rapid detection of Campylobacter species in ovine milk and hard cheese. Vet Med J Giza 44: 197-201.

26. EI-Nokrashy SA, EI-Magduib N, EI-Dairouty, RK (1997) Isolation, characterization and thermal inactivation of Campylobacter spp. from Egyptian raw milk. J Microbiol 32: 117-127.

27. El-Prince EM, Hussein AA, El Said MM (1998) A cohort study of Campylobacter species in dairy cows and infants and their mother's milk in Assiut governorate: 8th Scientific Congress (pp. 33-48). Assiut Egypt. Faculty of Veterinary Medicine, Assiut University,

28. Barakat A, ElFadly MM, Zaki AA (2015) Zoonotic hazards of campylobacteriosis in some areas in Egypt. Life Sci J 12: 9-14.

29. El-Zamkan MA, Abdel Hameed KG (2016) Prevalence of Campylobacter jejuni and Campylobacter coli in raw milk and some dairy products. Vet World 9: 1147-1151.

30. Ouf SA, Yehia RS, Ouf AS, Abdul-Rahim RF (2018) Bacterial contamination and health risks of drinking water from the municipal non-government managed water treatment plants. Environ Monit Assess 90: 685.

31. Elfadaly HA, Hassanain NA, Hassanain MA, Barakat AM, Shaapan RM (2018) Evaluation of primitive ground water supplies as a risk factor for the development of major waterborne zoonosis in Egyptian children living in rural areas. J Infect Public Health 11: 203-208.

32. Hamer R, Chen PY, Armitage JP, Reinert G, Deane CM (2010) Deciphering chemotaxis pathways using cross species comparisons. BMC Syst Biol 4: 1-19.

33. Konkel ME, Garvis SD, Tipton S, Anderson DE Jr, Cieplak W Jr (1997) Identification and molecular cloning of a gene encoding a fibronectin binding protein (CadF) from Campylobacter jejuni. Mol Microbiol 24: 953-963. 
34. Bang DD, Scheutz F, Ahrens P, Pedersen K, Blom J, Madsen M (2001) Prevalence of cytolethal distending toxin $(c d t)$ genes and CDT production in Campylobacter spp. isolated from Danish broilers. J Med Microbio 50: 1087-1094.

35. Doyle MP, Erickson MC (2008) Summer meeting 2007 - the problems with fresh produce: an overview. J Appl Microbiol 105: 317-330.

36. Wierzba TF, Abdel-Messih IA, Gharib B, Baqar S, Hendaui A, Khalil I, Omar TA, Khayat HE, Putnam SD, Sanders JW, Ng LK, Price LJ, Scott DA, Frenck RR (2008) Campylobacter infection as a trigger for Guillain-Barre Syndrome in Egypt. PLoS ONE 3: e3674.

37. Quinn PJ, Carter ME, Markey B, Carter GR (1994) Campylobacter species. In: Clinical Veterinary Microbiology. London: Wolfe/Mosby Publishing Press. 268-272.

38. Man SM, Kaakoush NO, Octavia S, Mitchell H (2010) The internal transcribed spacer region, a new tool for use in species differentiation and delineation of systematic relationships within the Campylobacter genus. Appl Environ Microbiol 76: 3071-3081.

39. Mikhail IA, Bourgeois AL, Hyams KC, Podgore JK, Lissner CR, Walz S (1987) In vitro activity of ciprofloxacin compared to trimethoprim-sulfamethoxazole against Campylobacter spp., Shigella spp. and Enterotoxigenic Escherichia coli causing travellers' diarrhea in Egypt. Scand J Infect Dis 9: 497981.

40. Putnam SD, Frenck, RW, Riddle MS, El-Gendy A, Taha NN, Pittner BT, Abu-Elyazeed R, Wierzba TF, Rao MR, Savarino SJ, Clemens JD (2003) Antimicrobial susceptibility trends in Campylobacter jejuni and Campylobacter coli isolated from a rural Egyptian pediatric population with diarrhea. Diag Microbiol Infect Dis 47: 601-608.

41. Said MM, El-Mohamady H, El-Beih FM, Rockabrand DM, Ismail TF, Monteville MR, Ahmed SF, Klena JD, Salama MS (2010) Detection of gyrA mutation among clinical isolates of
Campylobacter jejuni isolated in Egypt by MAMA PCR. J Infect Dev Ctries. 4: 546-554. doi: 10.3855/jidc.963

42. Hassan KE, Mansour A, Shaheen H, Amine M, Riddle MS, Young SYN, Sebeny P, Levin S (2014) The impact of household hygiene on the risk of bacterial diarrhea among Egyptian children in rural areas, 2004-2007. J Infect Dev Ctries. 8: 1541-1551. DOI 10.3855/jidc.4539

43. Helmy YA, El-Adawy H, Abdelwhab EM (2017) A comprehensive review of common bacterial, parasitic and viral zoonoses at the human-animal interface in Egypt. Pathogens 6: $1-28$.

44. Wafaa AA, Awaad MH, Nagwa SR (2016) A trial for prevention of Campylobacter jejuni infection in broiler chickens using autogenus bacterin. Asian J Poult Sci 10: 7885 .

45. Wafaa AA, Awaad MH, Nagwa SR (2015) The efficacy of certain feed additives for the prevention of Campylobacter jejuni infection in broiler chickens. Asian J Anim Sci 9: 427433.

46. Ghareeb K, Awad WA, Mohnl M, Porta R, Biarnés M, Böhm J, Schatzmayr G (2012) Evaluating the efficacy of an avianspecific probiotic to reduce the colonization of Campylobacter jejuni in broiler chickens. Poult Sci 91: 1825-1832.

\section{Corresponding author}

Wafaa A. Abd El-Ghany

Professor of Poultry Diseases, Poultry Diseases Department

Faculty of Veterinary Medicine, Cairo University

Giza Square, 12211, Giza, Egypt

Tel: +02 01224407992

Email:wafaa.ghany@yahoo.com

Conflict of interests: No conflict of interests is declared. 